\title{
An Overview of Self-Grown Nanostructured Electrode Materials in Electrochemical Supercapacitors
}

\author{
Nanasaheb M. Shinde*, Je Moon Yun*, Rajaram S. Mane**, \\ Sanjay Mathur***, and Kwang Ho Kim********,† \\ *Global Frontier R\&D Center for Hybrid Interface Materials, Pusan National University, Busan 46241, Korea \\ **National Core Research Center for Hybrid Materials Solution, Pusan National University, Busan 46241, Korea \\ ***Department of Chemistry, Institute of Inorganic Chemistry, University of Cologne, Cologne 50939, Germany \\ ****School of Materials Science and Engineering, Pusan National University, Busan 46241, Korea
}

(Received May 18, 2018; Revised June 11, 2018; Accepted June 19, 2018)

\begin{abstract}
Increasing demand for portable and wireless electronic devices with high power and energy densities has inspired global research to investigate, in lieu of scarce rare-earth and expensive ruthenium oxide-like materials, abundant, cheap, easily producible, and chemically stable electrode materials. Several potential electrode materials, including carbon-based materials, metal oxides, metal chalcogenides, layered metal double hydroxides, metal nitrides, metal phosphides, and metal chlorides with above requirements, have been effectively and efficiently applied in electrochemical supercapacitor energy storage devices. The synthesis of self-grown, or in-situ, nanostructured electrode materials using chemical processes is well-known, wherein the base material itself produces the required phase of the product with a unique morphology, high surface area, and moderate electrical conductivity. This comprehensive review provides in-depth information on the use of self-grown electrode materials of different morphologies in electrochemical supercapacitor applications. The present limitations and future prospects, from an industrial application perspectives, of self-grown electrode materials in enhancing energy storage capacity are briefly elaborated.
\end{abstract}

Key words : Self-grown nanostructures, Morphologies, Electrochemical supercapacitors, Energy density, Power density

\section{Introduction}

$\mathrm{T}$ he appearance of technology-inspired industries like the internet, mobile devices, and robotics has inspired researchers to think wisely and smartly regarding electricity sources. The use of electricity from electrochemical energy storage devices, like batteries and supercapacitors, has been studied for several decades; the discovery of these storage devices has made a dramatic change in society. ${ }^{1,2)}$ To fabricate batteries with high energy density, researchers have focused on decreasing their size and weight. The manufacture of transparent and flexible batteries has also gained noticeable attention for use in smart, wearable, and stretchable display systems. Meanwhile, continuously diminishing oil resources have directed industrialists and researchers to seek alternative available fuel sources through the motto, "Need is an Origin of Search." Electrochemical energy storage devices like batteries, supercapacitors, fuel cells, photoelectrochemical solar cells, and electrocatalyzers have their own advantages as well as disadvantages. ${ }^{3)}$ For example, batteries demonstrate high energy density but low power density, whereas fuel cells reveal the opposite of it. Electrochemical devices showing both high

\footnotetext{
Corresponding author: Kwang Ho Kim

E-mail : kwhokim@pusan.ac.kr

Tel : +82-51-510-3391 Fax : +82-5-1514-4457
}

power and energy are commonly known as electrochemical supercapacitors (ESs) or simply supercapacitors. They came into existence as a bridge between batteries and fuel cells. ${ }^{4)}$ For example, in cold countries where the average yearly temperature is below $0^{\circ} \mathrm{C}$, such as Iceland, the USA, the UK, Japan, Europe, Australia, and even Korea, starting motor engines early in the day or at night can be difficult, as the available batteries have insufficient power. Electronic tools fabricated in small-scale industries should have high energy and power densities for efficient and effective operations. The batteries have considerable energy density but limited power density, thereby a sudden acceleration/deceleration actions experience lag. For example, in subway systems, rapid action is essential. In most batteries, carbonaceous materials are used wherein electrochemical energy storage occurs by ionic adsorption/desorption process; ESs with high power and energy are preferred. The lack of conductivity of carbonaceous materials like graphite, diamond, carbon black, fullerenes, carbon nanotubes, and graphene has made them electrochemically inactive, although they have enormous applicability in dye-sensitized solar cells, hydrogen evolution, oxygen evolution, lithium-ion batteries, supercapacitors, photocatalytic degradation of organic pollutants, and electrochemical/bio sensors. In these cases, the nanostructures of metal oxides are widely being considered as electrode materials. Their miniaturized dimensions can offer unique electrical, structural, optical, thermal, and 


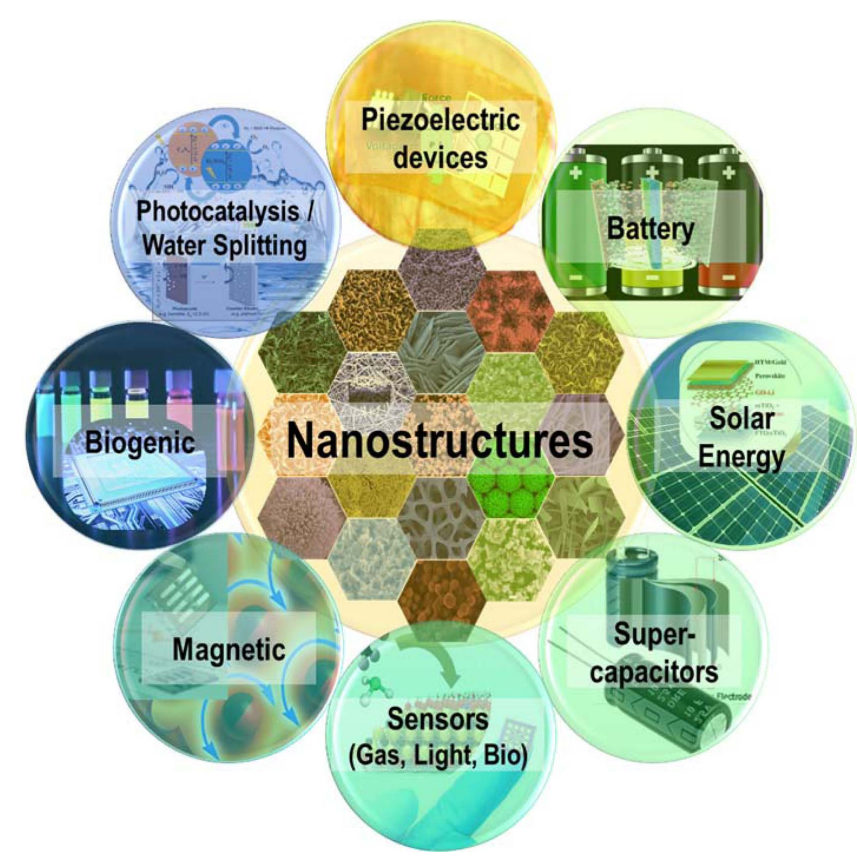

Fig. 1. Schematic view presenting some nanostructures and possible applications.

mechanical properties. With their reduced dimensions, they show higher surface area and quantum size effect. Various known nanostructures and their plausible applications are sketched in Fig. 1. Each application demands a list of specific properties. For example, the electrode materials used in solar cells should absorb photons at or near the ultraviolet/infrared (UV/IR) wavelength range for producing a better light-to-electrical power conversion efficiency; here, materials like silicon and perovskite are dominant.

From the materials selection perspective, the search for ESs materials is in a better position than that for battery materials, which have already been reached at a plateau in the context of storage performance. However, batteries are well-commercialized, whereas the development of ESs is in their early stage beginning. To identify the basic operation difference between the batteries and ESs, cyclic-voltamme- try (CV) and galvanostatic charge-discharge (GCD) measurements are used (Fig. 2). After the exploration of expensive and scarce ruthenium oxide and other rare earth materials, researchers have specifically investigated ecofriendly and economic electrode materials for comparable or superior performance. ${ }^{5,6)}$ The inorganic electrode materials used in ESs should, in general, be catalytically active, high in surface area, moderate in conductivity, and high in thermal, chemical, and structural stability, with several active sites for redox reactions. High values of specific capacitance (SC), energy density (ED), and power density (PD) are essentially important for commercial ESs. Similar charging and discharging is another basic requirement for ESs devices. ${ }^{7}$ Symmetric and asymmetric devices are two major types of ES devices; however, their definitions are somewhat contradictory. In a symmetric device, both anode and cathode should be of the same electrode materials; if they are of different materials, the device is commonly called an asymmetric ES. There is some confusion about how to distinguish battery and supercapacitor behaviors in hybrid, composite, and asymmetric ES systems. The two-electrodebased GCD profiles are used to distinguish their behavior. ${ }^{8)}$ The article titled "To be or not be" provides great support in understanding the nature of an electrode material as either a battery or supercapacitor. ${ }^{9)}$ In batteries, an upward shift in the voltage with a plateau-type redox peak behavior is typical; in ESs, a symmetric triangular characteristic of the electrode material is maintained in its charge-discharge profile as a plot of voltage versus time.

As discussed above, the choice of electrode materials is critical and important. For example, if the electrode material is in powder form, it must be mixed with a suitable binder like polyvinylidene fluoride before it is fixed onto a current -collecting electrode. This not only increases the electrode resistance because of its mass, but also impedes the electrochemical performance by reducing the charge transportation rate. Additionally, this type of synthesized electrode obstructs electrolyte ions from reaching deep level, thereby limiting greatly the inner-site accessibility of electrode materials. These actions impair electrochemical energy
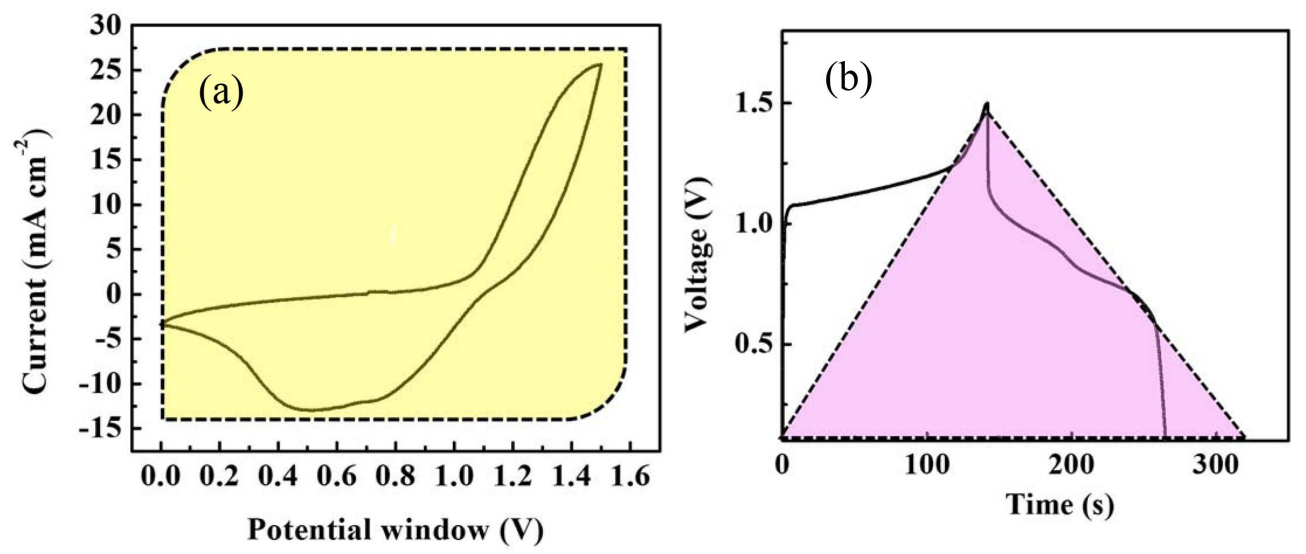

Fig. 2. Basic operation difference in batteries and ESs through cyclic voltammetry (CV) (a) and GCD scans (b). 
storage performance. Alternatively, researchers have grown various electrode materials like metal oxides, hydroxides, chalcogenides, nitrides, carbides, and phosphides in different morphologies directly onto conducting charge collectors, including fluorine-doped tin oxide, indium-doped tin oxide, stainless steel (SS), and titanium foil. The merits of 3-D nickel foam $(\mathrm{NiF})$ and copper foams obtained using various physical and chemical methods in different nano-forms have been discussed in detail in many previous reviews. ${ }^{10,11)}$ The morphology, surface area, available active sites, and conductivity of electrode materials must be scrutinized before using them as electrode materials in ESs. If both the morphology and the structure of the electrode materials are not stable, then long-term electrochemical operations are impractical. Here, their structures or morphologies can be modified due to instability and ultimately reduce the electrochemical performance by increasing the electrochemical charge transfer resistance. In terms of base materials choice, 3-D NiF has received worldwide attention as it a) offers easy and fast percolation of electrolyte ions, and b) provides smaller diffusion lengths for several redox reactions (relative to 2 -D conducting electrode materials). However, the mismatching lattice structure of product materials with $3-\mathrm{D} \mathrm{NiF}$ as a base material generates a high series resistance. ${ }^{12)}$ Thereby, the self- or in-situ growth of these electrode materials from the same conductive base material has received significant attention as it: a) offers a good lattice match between the base conductive material and the product material, b) provides fast and easy charge transportation, and c) enables the production of different morphologies with different surface areas, which increases the overall redox reaction rate and thus the electrochemical performance (Fig. 3). ${ }^{13)}$ An overview of self-grown electrode materials used in ES applications is given here in brief. The electrochemical operation details of ESs are discussed ini-

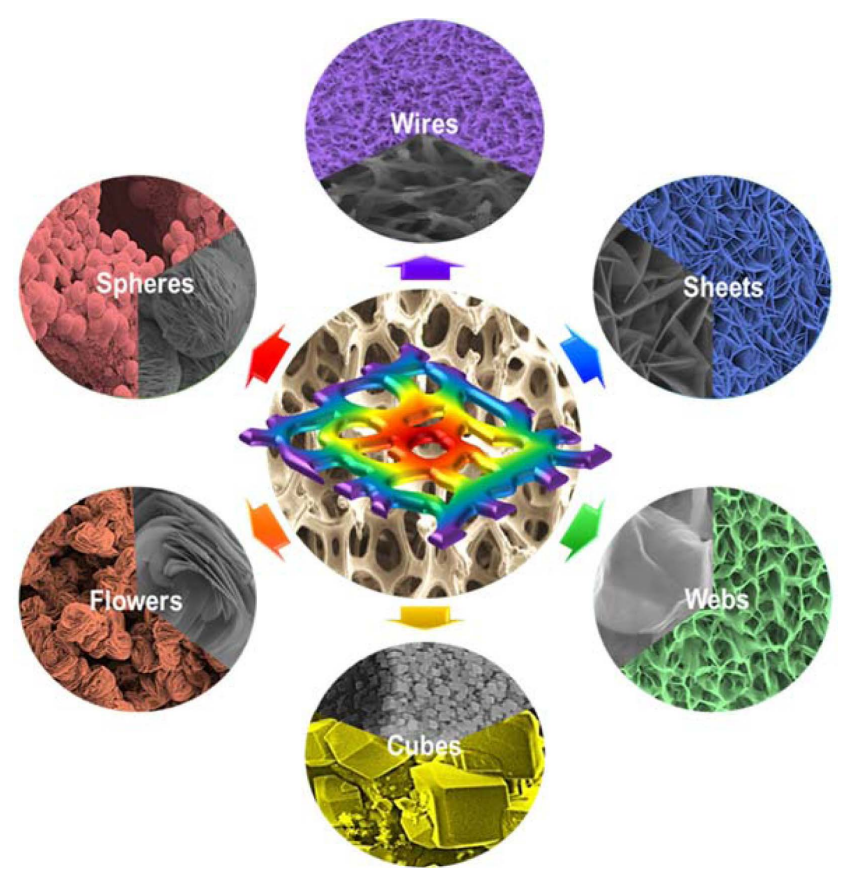

Fig. 3. Metal oxide/hydroxide morphologies obtained on 3-D $\mathrm{NiF}$ by using various chemical methods.

tially. At the end, electrochemical energy storage data available in the literature on various self-grown nanostructured electrode materials, regarding morphology, SC, ED, PD, stability, and other properties are well-summarized in Table 1. Before concluding, known challenges and application prospects are also explored.

\section{Electrochemical Supercapacitors}

Review articles describing the importance of energy storage devices based on ESs are found in the literature. ${ }^{5-10)}$ It is

Table 1. Summary of in-situ Grown Nanostructured Electrode Materials and Their Electrochemical Supercapacitive Performance (two/three electrode system)

\begin{tabular}{|c|c|c|c|c|c|c|c|c|c|}
\hline \multirow{3}{*}{$\begin{array}{l}\text { Sr. } \\
\text { No. }\end{array}$} & \multirow{3}{*}{$\begin{array}{l}\text { Synthesis method; } \\
\text { Experimental conditions }\end{array}$} & \multirow{3}{*}{$\begin{array}{c}\text { Product } \\
\text { and } \\
\text { Morphology }\end{array}$} & \multicolumn{6}{|c|}{ Supercapacitor configuration } & \multirow{3}{*}{ Ref. } \\
\hline & & & \multicolumn{2}{|c|}{ Three-electrode system } & \multicolumn{4}{|c|}{ Two electrode system } & \\
\hline & & & SCs & $\begin{array}{l}\text { Cyclability } \\
\text { (cycle) }\end{array}$ & SCs & ED & PD & $\begin{array}{l}\text { Stability } \\
\text { (cycle) }\end{array}$ & \\
\hline 1 & $\begin{array}{l}\text { Anodization: } 30 \mathrm{~mA} \mathrm{~cm}-2 \text { for } 800 \mathrm{~s} \text { at } 20^{\circ} \mathrm{C} \text { on } \\
10 \times 15 \mathrm{~mm} \mathrm{CuF} \mathrm{in} 3 \mathrm{M} \mathrm{KOH}\end{array}$ & $\begin{array}{l}\mathrm{Cu}(\mathrm{OH})_{2} \\
\text { Nanorods }\end{array}$ & $\begin{array}{c}1.8 \\
\mathrm{~F} \mathrm{~cm}^{-2}\end{array}$ & $\begin{array}{c}87.23 \% \\
(5000)\end{array}$ & - & - & - & - & 20) \\
\hline 2 & $\begin{array}{l}\text { Hydrothermal: } 0.8 \mathrm{~g} \text { sodium dodecyl sulfate } \\
(0.07 \mathrm{M}), 0.12 \mathrm{~g} \text { polyvinyl alcohol }(0.07 \mathrm{M}) \\
4.80 \mathrm{~g} \text { of } \mathrm{NaOH}, 1.37 \mathrm{~g}(\mathrm{NH} 4)_{2} \mathrm{~S}_{2} \mathrm{O}_{8} \text { in } \mathrm{NaOH}\end{array}$ & $\begin{array}{l}\mathrm{CuO} \\
\text { Flower, } \\
\text { Coral, } \\
\text { Sphere }\end{array}$ & $\begin{array}{l}520 \\
\mathrm{~F} \mathrm{~g}^{-1}\end{array}$ & $\begin{array}{c}95 \% \\
(3500)\end{array}$ & - & - & - & - & 21) \\
\hline 3 & $\begin{array}{l}\text { Anodization: } 30 \mathrm{~mA} \mathrm{~cm}-2 \text { for } 1200 \mathrm{~s} \text { on } \mathrm{CuF} \text { in } \\
3 \mathrm{M} \mathrm{KOH} \text { at } 40^{\circ} \mathrm{C}\end{array}$ & $\begin{array}{l}\mathrm{CuO} / \mathrm{Cu}_{2} \mathrm{O} \\
\text { Leaf-like }\end{array}$ & $\begin{array}{l}1.954 \\
\mathrm{~F} \mathrm{~g}^{-1}\end{array}$ & $\begin{array}{l}120 \% \\
(5000)\end{array}$ & - & - & - & - & 22) \\
\hline 4 & $\begin{array}{l}\text { Anodization: } \mathrm{Cu}(\mathrm{OH})_{2} \text { nanowires were pre- } \\
\text { pared using anodization (current is not pro- } \\
\text { vided) and then Ni-Co LDH was } \\
\text { electrodepositionally grown from nickel(II) } \\
\text { nitrate and cobalt(II) nitrate }\end{array}$ & $\begin{array}{l}\text { Ni-Co-LDH } \\
\text { Nanowire }\end{array}$ & $\begin{array}{l}2170 \\
\mathrm{~F} \mathrm{~g}^{-1}\end{array}$ & $\begin{array}{l}80.46 \% \\
(2000)\end{array}$ & $\begin{array}{l}159 \\
\mathrm{~F} \mathrm{~g}^{-1}\end{array}$ & $\begin{array}{l}32.67 \\
\mathrm{~W} \mathrm{~h} \mathrm{~kg}\end{array}$ & $\begin{array}{c}350 \\
\mathrm{~W} \mathrm{~kg}^{-1}\end{array}$ & & 23) \\
\hline 5 & $\begin{array}{l}\text { Hydrothermal: } 1-\mathrm{M} \text { sodium selenite at } 120^{\circ} \mathrm{C} \\
\text { for } 12 \mathrm{~h}\end{array}$ & $\begin{array}{c}\text { CuSe } \\
\text { Nanoneedle }\end{array}$ & $\begin{array}{l}1037.5 \\
\mathrm{~F} \mathrm{~g}^{-1}\end{array}$ & $\begin{array}{l}118 \% \\
(2000)\end{array}$ & - & - & - & - & 24) \\
\hline
\end{tabular}


Table 1. Continued

\begin{tabular}{|c|c|c|c|c|c|c|c|c|c|}
\hline \multirow{3}{*}{$\begin{array}{l}\text { Sr. } \\
\text { No. }\end{array}$} & \multirow{3}{*}{$\begin{array}{l}\text { Synthesis method; } \\
\text { Experimental conditions }\end{array}$} & \multirow{3}{*}{$\begin{array}{l}\text { Product } \\
\text { and } \\
\text { Morphology }\end{array}$} & \multicolumn{6}{|c|}{ Supercapacitor configuration } & \multirow{3}{*}{ Ref. } \\
\hline & & & \multicolumn{2}{|c|}{ Three-electrode system } & \multicolumn{4}{|c|}{ Two electrode system } & \\
\hline & & & $\mathrm{SCs}$ & $\begin{array}{l}\text { Cyclability } \\
\text { (cycle) }\end{array}$ & $\mathrm{SCs}$ & $\mathrm{ED}$ & $\mathrm{PD}$ & $\begin{array}{l}\text { Stability } \\
\text { (cycle) }\end{array}$ & \\
\hline 6 & $\begin{array}{l}\text { Hydrothermal: } 15 \mathrm{~mL} \mathrm{HCl}(\mathrm{pH}=3.0) \text { at } \\
180^{\circ} \mathrm{C} \text { for } 6 \mathrm{~h}\end{array}$ & $\begin{array}{c}\mathrm{Ni}(\mathrm{OH})_{2} \\
\text { Nanoflake }\end{array}$ & $\begin{array}{l}1228 \\
\mathrm{~F} \mathrm{~g}^{-1}\end{array}$ & $\begin{array}{c}100 \% \\
(1000)\end{array}$ & - & - & - & - & 28) \\
\hline 7 & $\begin{array}{l}\text { Hydrothermal: } 50 \mathrm{~mL} \text { water, } \mathrm{Fe}\left(\mathrm{NO}_{3}\right)_{3} \text { in } 0.1 \text {, } \\
1 \text {, and } 5 \mathrm{mmol} \text {, at } 120^{\circ} \mathrm{C} \text { for } 4 \mathrm{~h}\end{array}$ & $\begin{array}{c}\mathrm{Ni}(\mathrm{OH})_{2} \\
\text { Nanosheet }\end{array}$ & $\begin{array}{l}1100 \\
\mathrm{~F} \mathrm{~g}^{-1}\end{array}$ & - & - & - & - & - & 29) \\
\hline 8 & $\begin{array}{l}\text { Hydrothermal: } 15 \text { wt. } \% 30 \mathrm{~mL} \mathrm{H}_{2} \mathrm{O}_{2} \text { at } 180^{\circ} \mathrm{C} \\
\text { for } 24 \mathrm{~h}\end{array}$ & $\begin{array}{l}\mathrm{Ni}(\mathrm{OH})_{2} \\
\text { Hex agonal } \\
\text { Nanoplate }\end{array}$ & $\begin{array}{l}2534 \\
\mathrm{~F} \mathrm{~g}^{-1}\end{array}$ & $\begin{array}{c}97 \% \\
(2000)\end{array}$ & - & - & - & - & 30) \\
\hline 9 & $\begin{array}{l}\text { Dry annealing: } 3 \mathrm{M} \mathrm{HCl} \text { for } 20 \text { min at } 80^{\circ} \mathrm{C} \\
\text { for } 20 \text { days. For sulfurization, obtained } \\
\mathrm{Ni}(\mathrm{OH})_{2} \text { was kept in a porcelain boat contain- } \\
\text { ing } 1 \mathrm{~g} \text { thiourea which was heated in } \mathrm{N}_{2} \\
\text { atmosphere }\end{array}$ & $\begin{array}{c}\mathrm{Ni}(\mathrm{OH})_{2} \\
\text { Nanobrush }\end{array}$ & $\begin{array}{l}5.59 \\
\mathrm{~F} \mathrm{~cm}^{-2}\end{array}$ & $\begin{array}{l}94.9 \% \\
(10000)\end{array}$ & $\begin{array}{l}16.74 \\
\mathrm{~F} \mathrm{~cm}^{-3}\end{array}$ & $\begin{array}{c}4.56 \\
\mathrm{~mW} \mathrm{~h} \mathrm{~cm}\end{array}$ & $\begin{array}{l}100.04 \\
\mathrm{~mW} \mathrm{~cm}\end{array}$ & $\begin{array}{c}96.5 \% \\
(10000)\end{array}$ & 31) \\
\hline 10 & $\begin{array}{l}\text { Hydrothermal: } 2 \mathrm{M} \mathrm{HCl} \text {, thioacetamide, } \\
\text { deionized water, and absolute ethanol at } \\
120^{\circ} \mathrm{C} \text { for } 6 \mathrm{~h}\end{array}$ & $\begin{array}{l}\mathrm{Ni}_{3} \mathrm{~S}_{2} \\
\text { Hierarchi- } \\
\text { cal dendrite }\end{array}$ & $\begin{array}{l}710 \\
\mathrm{~F} \mathrm{~g}^{-1}\end{array}$ & $\begin{array}{c}100 \% \\
(2000)\end{array}$ & - & - & - & & 32) \\
\hline 11 & $\begin{array}{l}\text { Hydrothermal: } 0.15 \mathrm{M} \text { thiourea and } 75 \mathrm{~mL} \\
\text { water heated at } 150^{\circ} \mathrm{C} \text { for } 4 \mathrm{~h}\end{array}$ & $\begin{array}{l}\mathrm{Ni}_{3} \mathrm{~S}_{2} \\
\text { Nest like }\end{array}$ & $\begin{array}{l}1293 \\
\mathrm{~F} \mathrm{~g}\end{array}$ & $\begin{array}{c}69 \% \\
(2000)\end{array}$ & - & - & - & - & 33) \\
\hline 12 & $\begin{array}{l}\text { Hydrothermal: } 3 \mathrm{M} \mathrm{HCl} \text { soaked for } 20 \mathrm{~min} \text { at } \\
90^{\circ} \mathrm{C} \text { and dried at room temperature }\end{array}$ & $\begin{array}{l}\mathrm{Ni} @ \mathrm{NiO} \\
\text { Numerous } \\
\text { ravine }\end{array}$ & $\begin{array}{l}2.0 \\
\mathrm{~F} \mathrm{~cm}^{-2}\end{array}$ & $\begin{array}{c}170 \% \\
(100000)\end{array}$ & $\begin{array}{l}1.38 \\
\mathrm{~F} \mathrm{~cm}\end{array}$ & $\begin{array}{l}1.06 \\
\mathrm{~mW} \mathrm{~h} \mathrm{~cm}\end{array}$ & $\begin{array}{c}0.42 \\
\mathrm{~W} \mathrm{~cm}\end{array}$ & $100 \%$ & 34) \\
\hline 13 & $\begin{array}{l}\text { Hydrothermal: } 5 \text { mmol sulfur powder and } 16 \\
\mathrm{~mL} \text { anhydrous ethanediamine in } 16 \mathrm{~mL} \text { ethyl } \\
\text { alcohol at } 160^{\circ} \mathrm{C} \text { for } 6,12,24 \mathrm{~h}\end{array}$ & $\begin{array}{c}\beta \text {-NiS } \\
\text { Nanorod }\end{array}$ & $\begin{array}{l}1158 \\
F g^{-1}\end{array}$ & $\begin{array}{l}97.4 \% \\
(2000)\end{array}$ & $\begin{array}{c}113 \\
\mathrm{~F} \mathrm{~g}^{-1}\end{array}$ & $\begin{array}{l}55.1 \\
\text { W h kg }\end{array}$ & $\begin{array}{c}925.9 \\
\mathrm{~W} \mathrm{~kg}\end{array}$ & $\begin{array}{c}97 \% \\
(2000)\end{array}$ & $35)$ \\
\hline 14 & 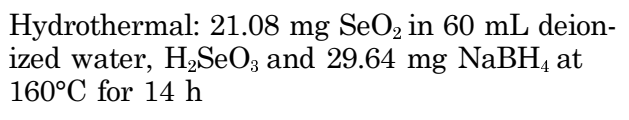 & $\begin{array}{c}\mathrm{Ni}_{3} \mathrm{Se}_{2} \\
\text { Nanosheet }\end{array}$ & $\begin{array}{c}854 \\
\mathrm{~F} \mathrm{~g}^{-1}\end{array}$ & $\begin{array}{l}87.23 \% \\
(5000)\end{array}$ & $\begin{array}{l}131.1 \\
\mathrm{~F} \mathrm{~g}^{-1}\end{array}$ & $\begin{array}{c}23.3 \\
\text { W h kg }\end{array}$ & $\begin{array}{c}398.1 \\
\text { W kg }\end{array}$ & $\begin{array}{c}91.11 \% \\
(5000)\end{array}$ & 36) \\
\hline 15 & $\begin{array}{l}\text { Hydrothermal: } 14 \mathrm{~mL} \text { DMF and } 1 \mathrm{~mL} \text { EDA, } \\
0.0410 \text { g selenium powder, and } 0.1093 \mathrm{~g}(0.3 \\
\text { mmol }) \text { CTAB at } 160^{\circ} \mathrm{C} \text { for } 24 \mathrm{~h}\end{array}$ & $\begin{array}{c}\text { NiSe } \\
\text { Microsphere }\end{array}$ & $\begin{array}{c}492 \\
\mathrm{~F} \mathrm{~g}^{-1}\end{array}$ & $\begin{array}{c}84.6 \% \\
(200)\end{array}$ & - & - & - & - & 37) \\
\hline 16 & $\begin{array}{l}\text { Hydrothermal: } 20 \mathrm{mg} \text { of } \mathrm{TeO}_{2}, 15 \mathrm{~mL} \mathrm{~N} \mathrm{H}_{4} \\
\mathrm{H}_{2} \mathrm{O} \text { and } 55 \mathrm{~mL} \text { distilled water at } 180^{\circ} \mathrm{C} \text { for } \\
18 \mathrm{~h}\end{array}$ & $\begin{array}{l}\text { NiTe/NiSe } \\
\text { Flake }\end{array}$ & $\begin{array}{l}1868 \\
F g^{-1}\end{array}$ & $\begin{array}{l}81.2 \% \\
(1000)\end{array}$ & $\begin{array}{l}94.9 \\
\mathrm{~F} \mathrm{~g}^{-1}\end{array}$ & $\begin{array}{c}33.7 \\
\mathrm{~W} \mathrm{~h} \mathrm{~kg}\end{array}$ & $\begin{array}{c}4000 \\
\text { W kg }\end{array}$ & $\begin{array}{l}86.2 \% \\
(5000)\end{array}$ & 38) \\
\hline 17 & $\begin{array}{l}\text { Hydrothermal: } 20 \mathrm{mg} \mathrm{TeO}_{2} \text { and } \mathrm{SeO}_{2} \text { in } 55 \\
\mathrm{~mL} \text { deionized water, and } 15 \mathrm{~mL}_{2} \mathrm{H}_{4} \cdot \mathrm{H}_{2} \mathrm{O} \text { at } \\
180^{\circ} \mathrm{C} \text { for } 18 \mathrm{~h}\end{array}$ & $\begin{array}{l}\text { NiTe } \\
\text { Flake }\end{array}$ & $\begin{array}{l}603.6 \\
\mathrm{~F} \mathrm{~g}^{-1}\end{array}$ & $\begin{array}{l}93.2 \% \\
(1000)\end{array}$ & $\begin{array}{l}119.9 \\
\mathrm{~F} \mathrm{~g}^{-1}\end{array}$ & $\begin{array}{c}42.7 \\
\text { W h kg-1 }\end{array}$ & $\begin{array}{c}800.6 \\
\mathrm{~W} \mathrm{~kg}\end{array}$ & $\begin{array}{c}76.4 \% \\
(10000)\end{array}$ & 39) \\
\hline 18 & $\begin{array}{l}\text { Anodization: } 300 \mathrm{mV} \mathrm{s}{ }^{-1} \text { scan rate (deposition } \\
\text { time not provided) }\end{array}$ & $\begin{array}{l}\mathrm{SnO} \\
\text { Nanoporous }\end{array}$ & $\begin{array}{c}274 \\
\mathrm{~F} \mathrm{~g} \\
-1\end{array}$ & $\begin{array}{c}85 \% \\
(1000)\end{array}$ & - & - & - & - & 44) \\
\hline 19 & $\begin{array}{l}\text { Anodization: } \mathrm{Ti} \text { foil in ethylene glycol solu- } \\
\text { tion, } 0.27 \text { wt. } \% \mathrm{NH}_{4} \mathrm{~F}, 30 \mathrm{~V} \text { for } 180 \mathrm{~min} \text { at } \\
\text { room temperature }\left(27^{\circ} \mathrm{C}\right)\end{array}$ & $\begin{array}{c}\mathrm{TiO}_{2} \\
\text { Nanotube }\end{array}$ & $\begin{array}{c}3.75 \\
\mu \mathrm{A} \mathrm{cm}^{-2}\end{array}$ & & - & - & - & & $45)$ \\
\hline 20 & $\begin{array}{l}\text { Anodization: } 20 \mathrm{~V} \text { and DI water in } 75: 25 \\
\text { ratio with } \mathrm{NH}_{4} \mathrm{~F}(0.5 \mathrm{wt} . \%) \text { at room tempera- } \\
\text { ture for } 1 \text { and } 5 \mathrm{~h} \text {, air-annealed at } 500^{\circ} \mathrm{C} \text { for } \\
2.5 \mathrm{~h}\end{array}$ & $\begin{array}{c}\mathrm{TiO}_{2} \\
\text { Nanotube }\end{array}$ & $\begin{array}{l}52 \\
\mu \mathrm{F} \mathrm{cm}^{-2}\end{array}$ & & - & - & - & - & 46) \\
\hline 21 & $\begin{array}{l}\text { Anodization: } 30 \mathrm{~V} \text { for } 180 \text { min at room tem- } \\
\text { perature in a glycerol aqueous solution ( } 90 \\
\left.\text { vol. } \% \text { glycerol: } 10 \text { vol. } \% \mathrm{H}_{2} \mathrm{O}\right) \text { containing } \\
0.75 \% \mathrm{NH}_{4} \mathrm{~F}\end{array}$ & $\begin{array}{c}\mathrm{TiO}_{2} \\
\text { Nanotube }\end{array}$ & $\begin{array}{l}3.24 \\
\mathrm{mF} \mathrm{cm}^{-2}\end{array}$ & $\begin{array}{c}68 \% \\
(1000)\end{array}$ & - & - & - & - & 47) \\
\hline 22 & $\begin{array}{l}\text { Anodization: } 0.5 \text { wt. } \% \mathrm{NH}_{4} \mathrm{~F} \text { ethylene glycol } \\
\text { solution at } 50 \mathrm{~V} \text { for } 3 \mathrm{~h} \text {, annealed at } 450^{\circ} \mathrm{C}\end{array}$ & $\begin{array}{c}\mathrm{TiO}_{2} \\
\text { Nanotube }\end{array}$ & $\begin{array}{l}740 \\
\mathrm{~F} \mathrm{~g}\end{array}$ & $\begin{array}{c}87 \% \\
(1000)\end{array}$ & - & - & - & - & 48) \\
\hline 23 & $\begin{array}{l}\text { Anodization: } 0.5 \mathrm{wt} . \% \mathrm{NH}_{4} \mathrm{~F} \text { ethylene glycol at } \\
50 \mathrm{~V} \text { for } 3 \mathrm{~h} \text {, second time anodization for at } \\
50 \mathrm{~V} \text { for } 30 \mathrm{~min}\end{array}$ & $\begin{array}{c}\mathrm{TiO}_{2} \\
\text { Nanotube }\end{array}$ & $\begin{array}{l}740 \\
\mathrm{~F} \mathrm{~g}^{-1}\end{array}$ & & - & - & - & - & 49) \\
\hline 24 & $\begin{array}{l}\text { Anodization: } 1 \mathrm{M} \text { oxalic acid with } 40 \mathrm{~V} \text { DC } \\
\text { power supply for } 25 \mathrm{~min} \text { at room temperature }\end{array}$ & $\begin{array}{l}\mathrm{TiO}_{2} \\
\text { Nanotube }\end{array}$ & $\begin{array}{l}91.43 \\
\mathrm{~F} \mathrm{~g}^{-1}\end{array}$ & & - & - & - & - & 50) \\
\hline
\end{tabular}


believed that the ESs operate by two mechanisms: electrochemical double-layer capacitance and pseudocapacitance. In the former, charge separation takes place at the electrode/electrolyte interface and is based on non-faradaic redox reactions; whereas in pseudocapacitance, charge separation takes place at the electrode surface through various faradaic redox reactions. Carbonaceous materials generally demonstrate the first charge-storage kinetics, while metal oxides, hydroxides, layered double hydroxides (LDHs), sulfides, selenides, tellurides, nitrides, and phosphides are documented as showing the second type. ${ }^{12)}$ Recently, the effective and efficient use of 2-D MXenes as electrode materials in ES devices has considerably increased. ${ }^{4)}$ ESs based on the lightweight carbonaceous materials demonstrate a high reversibility, long cycle life, good chemical stability, and structural robustness. However, a small number of adsorption/desorption sites places a limit on enhancing their performance. To improve their electrochemical energy storage performance, they should be functionalized, activated, and surface-treated or doped with metals or conducting polymers. On the addition of guest materials, the cycle life and the scan rate capability of host electrode materials are decreased, which can generate material swelling and shrinking issues. ${ }^{6,7)}$ The overall electrode resistance, i.e. interfacial resistance between the electrode material and the charge collector, electrolyte ion diffusion resistance in the electrode material as well as in the separator, and the electrolyte resistance are important in assembling ESs devices. In a nutshell, electrode materials should have high conductivity, large surface area, good corrosion resistance, high thermal stability, controlled-pore structure, easy processability and compatibility, economical sources, environment friendliness, and recycling potential before they implied as ES electrode materials for better performance. A three-electrode electrochemical system comprises the working electrode, reference electrode, and counter electrode, while a two-electrode system consists of a negative electrode (negatrode) and a positive electrode (positrode), separated by an ion-transportable insulting separator. In both cases, an efficient and stable electrolyte, either liquid, semiliquid, or polymer-based, should be used. Both aqueous and nonaqueous electrolyte solutions are used. On using acidic aqueous electrolytes, the chances of electrode corrosion are greater. Therefore, ESs using alkaline electrolyte solutions are practically important. ${ }^{3,4)}$ Various known mathematical relations can be used for estimating different electrochemical parameters, including the SC, voltage scan rate $(S)$, and interfacial capacitance $\left(C_{\mathrm{i}}\right)$ in an electrochemical three-electrode system. Higher values of $\mathrm{ED}$ and $\mathrm{PD}$ and $\mathrm{SC}$ with operational efficiency of the electrode materials in two-electrode ESs are required for practical viability. The electrochemical parameters obtained from GCD measurement are more accurate than those estimated from the cyclic voltammetry (CV) measurement, as in ESs the charge-discharge process is symmetrical. In both cases, the electrochemical impedance measurement illustrates the type of interfacial kinetics present across the electrode/electrolyte interface.

\section{Self-grown Synthesis Methods}

Myriad of physical and chemical methods have been applied to develop various electrode materials with different morphologies. These methods include electrodeposition, chemical bath deposition, successive ionic layer adsorption and reaction, electrodeposition, sol-gel, anodization, spray pyrolysis, liquid phase epitaxy, hydrothermal, spin coating, dip drying, polymerization, and reflux..$^{4,10,14)}$ In all these methods, the use of two precursors, i.e., positive metal ion salt and negative sulfide, selenide, telluride, or hydroxide reagent ions, is necessary. In each case, the deposition principle is different. For example, in the chemical wet deposition method when the ionic product is greater than the solubility product, the deposition of electrode material begins; meanwhile, in spray pyrolysis the formation of fine droplets and their condensation onto a hot substrate cause the evolution of the electrode material, which generally is a compact, adherent, shiny film. Notably, all methods described above generate either film or powder products. Products in compact film and powder forms have relatively less importance in ESs applications than directly grown porous nanostructured electrodes because of their limited surface area and insufficient availability of active surface sites for faradaic redox reactions. Thereby, the use of a suitable binder electrolyte to obtain an electrode material is required. While these products possess high surface area in morphologies including nanoplates, nanorods, nanotubes, nanobelts, nanoribbons, nanoflowers, and pine-twig-types on either nickel foam (NiF), copper, titanium, indium-doped tin oxide, fluorine-doped tin oxide, or SS substrates, ${ }^{4,6,10)}$ their performance is limited by an increased interfacial resistance between the base material and the product electrode. For example, the dye-sensitized solar cells assembled with titanium dioxide $\left(\mathrm{TiO}_{2}\right)$-SS demonstrate a very low power conversion efficiencies because of the high interfacial resistance between $\mathrm{TiO}_{2}$ and $\mathrm{SS}$. In the ESs of nickel oxide grown on 3-D NiF, a small electrical potential barrier exists across their interfaces. Alternatively, electrode materials obtained or derived from one single current-conducting material via self or in-situ growth can show several benefits. It is believed that: a) the generated charges can be easily and effectively collected at $\mathrm{NiF}$ by the low interfacial resistance, b) the product shows high surface area by offering an easy accessibility to electrolyte ions for deep-level percolation, thus promoting electrode accessibility, c) the diffusion lengths become shorter as the electrolyte ions are in contact with the electrode material from all the sides, and d) the electrolyte/electrode interfacial charge-transfer resistance is smaller. The processes adopted in forming the self-grown electrode materials include dry-annealing (oxidation, sulfurization, and selenization), electrochemical anodization, and hydrothermal. 
Tube furnace

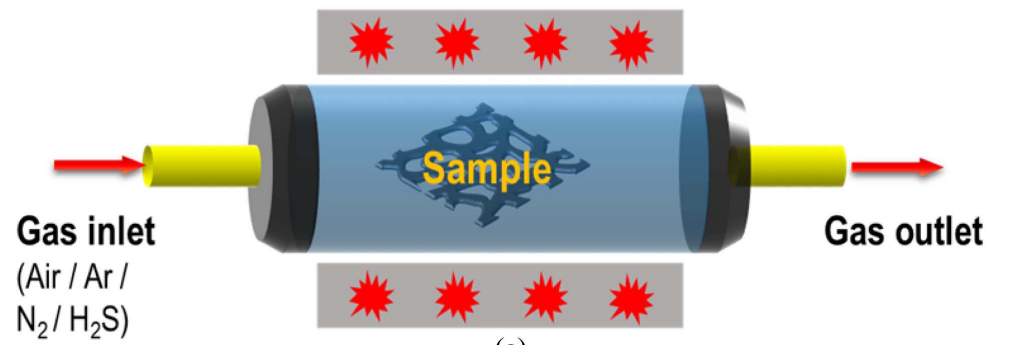

(a)

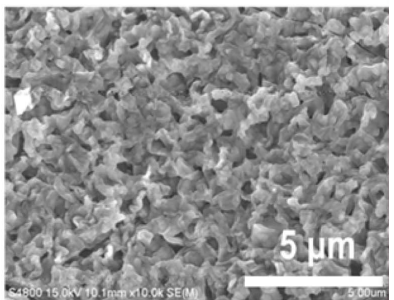

(b)

Fig. 4. Dry-annealing schematic (a) and field-emission scanning electron microscope (FE-SEM) surface image of dry-annealed $\mathrm{NiO}(b)$.

\subsection{Dry-annealing}

The process of dry-annealing involves the heating of electrode materials in environments like air, nitrogen, or sulfur to obtain the requisite products (Fig. 4) ${ }^{6)}$ For example, the chemically stable cubic $\mathrm{NaCl}$-type structured $\mathrm{NiO}$ can be grown on $\mathrm{NiF}$ through the $\mathrm{Ni}^{+}$and (1/2) $\mathrm{O}_{2}$ combination. Nickel oxidizes into $\mathrm{NiO}$ at about $500^{\circ} \mathrm{C}$ in air in a tubular or rectangular oven. It is believed that oxidation (or sulfurization, selenization, etc.) of surface metal atoms takes place by the transfer of electrons across the air/metal interface to form a monolayer of adsorbed oxygen ions, followed by the diffusion of oxygen ions into the metal region; i.e., a thin oxide layer forms on the metal surface on absorbing oxygen anions. In air annealing, during the initial growth stages, the metal atoms are redistributed at preferred sites and interact with the adsorbed species, resulting in the formation of nucleation sites, which are structural defects like grain boundaries, impurities, and dislocations. ${ }^{15)} \mathrm{A}$ metal oxide layer can form with the rapid growth of these oxide islands. High-temperature air-annealing promotes the growth of the metal oxide through the diffusion of metal cations into the obtained metal oxide. It is believed that oxygen can also penetrate the metal oxide cracks and micro-channels, enabling metal diffusion at higher temperature. Because the rate of metal cation diffusion is higher than that of oxygen anion diffusion, metal oxidation is favored by increasing the thickness of the metal oxide layer. The diffusion of metal cations or oxygen anions depends upon the host material structure, i.e., planar or 3-D, and the annealing temperature. One can transfer one material phase into another simply by changing the nature of the annealing environment; for example, $\mathrm{NiO}$ can be transferred into $\mathrm{NiS}$ on annealing $\mathrm{NiO}$ in $\mathrm{H}_{2} \mathrm{~S}$ gas at $400-500^{\circ} \mathrm{C}$ for $3-5 \mathrm{~h}$.

\subsection{Electrochemical anodization}

Electrochemical anodization, or simply anodization, is one of the common methods used to synthesize self-grown nanostructures in particular metal oxides. Anodization is an electrolytic process that creates a protective or decorative oxide film over a metallic surface under the application of a constant potential or current. ${ }^{16)}$ Anodization typically increases both the thickness and density of the layer formed

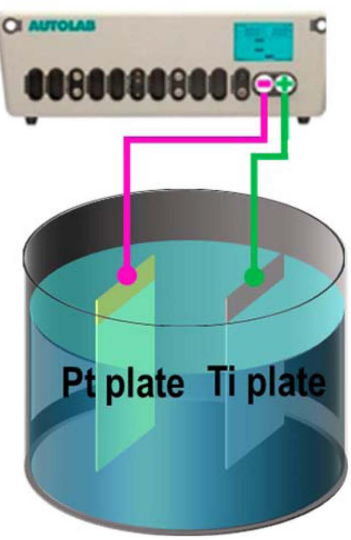

(a)

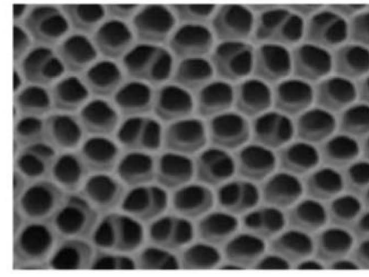

(b)
Fig. 5. Schematic of electrochemical anodization process using self-growth (a) and FE-SEM surface image of anodized $\mathrm{TiO}_{2}$ (b).

on the metal surface under consideration. When a high voltage is applied between the anode and the cathode, electrons are forced to move from the electrolyte solution towards the anode surface. This process leaves atoms of the metal surface exposed to oxygen ions within the electrolyte. These atoms react and become an in-situ integral part of the oxide layer. ${ }^{17)}$ The electrons, migrating through the voltage source, can return to the cathode. Under the appropriate electrolyte $\mathrm{pH}$, they react with hydrogen ions. During this process, the conducting electrode piece experiences anodization. The cathode is commonly a plate or rod of platinum (see Fig. 5 for experimental set-up and anodized $\mathrm{TiO}_{2}$ pores on Ti-foil). The deposition conditions like time period, applied voltage, temperature, surfactant, and electrolyte medium should be controlled carefully and precisely to obtain metal oxides of various thicknesses and morphologies. An ordered nanostructure, high resistance to abrasive wear, stability, ability to tune morphology and thickness through the applied voltage and reaction time, and lower weight of product materials are few merits of the anodization process. ${ }^{18)}$

\subsection{Hydrothermal}

As discussed in the introduction section, the synthesis of various nanostructured materials using binder-free chemi- 


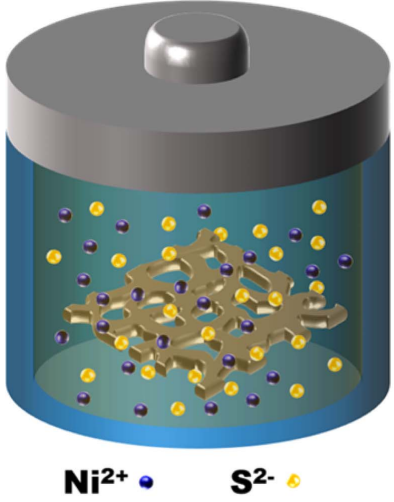

(a)

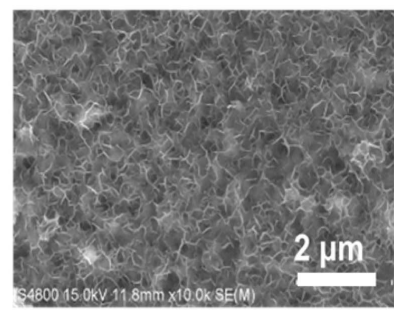

(b)
Fig. 6. Schematic of hydrothermal process used for in-situ $\mathrm{Ni}_{\mathrm{x}} \mathrm{S}_{\mathrm{y}}$ growth (a) and its FE-SEM image (b).

cal and physical methods on 3-D conducting foams has been reported extensively in the past. Hydrothermal methods permit the synthesis of electrode materials in various nanostructures on conducting and non-conducting substrate surfaces at temperatures of $\leq 200^{\circ} \mathrm{C}$ and ambient pressure. Electrode materials produced in this way show weak electrochemical energy storage potential because of various adverse issues like an accumulation of extra-electrode and the increase of interfacial resistance by inhomogeneous structure formation. ${ }^{2,3)}$ Weak adhesion between the materials induces the loss of active electrode material, which substantially decreases the device cycle life. ${ }^{10)}$ To overcome both limitations, self or in-situ growth can be a facile approach wherein the product electrode can be directly obtained from the same base current collector material if it is metallic. In this process, the base current collector is placed in a Teflonlined SS autoclave in the presence of a suitable solvent at an annealing temperature $<200^{\circ} \mathrm{C}$ for a few hours (Fig. 6). Because of the reaction bath pressure and temperature, the materials can be produced on the host metallic substrate surfaces as a byproduct. For example, nickel hydroxide $\left(\mathrm{Ni}(\mathrm{OH})_{2}\right)$ nanoplate-type electrodes have been obtained on the $\mathrm{NiF}$ from water and hydrogen peroxide through the reaction $\mathrm{Ni}+\mathrm{H}_{2} \mathrm{O}_{2} \rightarrow \mathrm{Ni}(\mathrm{OH})_{2}{ }^{6)}$ It is worthwhile to note, in the present case, that the $\mathrm{NiF}$ not only acts as a 3-D support for $\mathrm{Ni}(\mathrm{OH})_{2}$ but also serves as a nickel ion source. This creates an enhancement in electrical contact and strong mechanical adherence for fast and stable redox reactions with high ion diffusivity. Additionally, the obtained byproduct can show different morphologies without disturbing the original base material skeleton. For example, 2-D platelets of $\mathrm{Ni}(\mathrm{OH})_{2}$ are recently grown on 3-D NiF. ${ }^{6}$ ) On annealing it in a suitable environment, the formation of another phase can occur. For example, $\mathrm{NiO}$ can be obtained from the $\mathrm{Ni}(\mathrm{OH})_{2}$ by air annealing; to obtain $\mathrm{Ni}_{\mathrm{x}} \mathrm{S}_{\mathrm{y}}, \mathrm{Ni}(\mathrm{OH})_{2}$ should be annealed in $\mathrm{H}_{2} \mathrm{~S}$ gas at ambient temperature. On the other hand, dipping the obtained electrode material in an ionic solution can yield the requisite product phase by the Kirkendall effect. For example, NiSe can be obtained from
$\mathrm{NiO}$ by dipping in sodium selenosulfate solution at ambient temperature for a few hours.

\section{Self-grown ES Electrode Materials and Their Energy Storage Performance}

The electrochemical energy storage properties of a few self-grown electrode materials reported in the literature using the above mentioned soft chemical methods are summarized. In most of the cases, current collectors like copper, nickel, and titanium foils or foams are preferred. Electrode base materials like tin, zinc, and aluminum have rarely been considered for growing their respective metal oxides in ESs applications.

\subsection{Copper-based self-grown electrode materials}

In the past decade, because it has an appropriate redox potential, good electrochemical activity and excellent stability, $p$-type conductivity, and the band gap energy of $1.2 \mathrm{eV}$, copper oxide $(\mathrm{CuO})$ and its chalcogenides like copper sulfide and copper selenide ( $\mathrm{CuS}$ and $\mathrm{CuSe}$ ) have widely been addressed as the effective and efficient photocatalysts, gas sensors, and electrodes for solar cells and lithium ion batteries. Copper chalcogenides are nontoxic, cheap, abundant, and chemically stable materials. ${ }^{19)}$ Various nanostructures like nanotubes, nanowires, nanorods, nanoribbons, hollow structures, and leaf-like morphologies of $\mathrm{CuO}$ are wellknown. Zhao et al. synthesized copper hydroxide $\left[\mathrm{Cu}(\mathrm{OH})_{2}\right]$ nanorods on copper foam $(\mathrm{CuF})$ using the $\mathrm{CuF}$ as the copper source through a facile and scalable one-step anodization method, which was further used as a binder-free electrode material for ESs with an areal SC reaching $1.889 \mathrm{~F} \mathrm{~cm}^{-2}$ at a scan rate of $2 \mathrm{mV} \mathrm{s}^{-1}$, the low intrinsic resistance of 0.792 $\Omega \mathrm{cm}^{-2}$, and $87.23 \%$ cycling stability after 5000 cycles. ${ }^{20)}$ Luo et al. synthesized flower-shaped $\mathrm{CuO}$ as a high-performance ES electrode material using an alkaline solution oxidation method in the presence of sodium dodecyl sulfate as the surfactant. ${ }^{21)}$ This electrode delivered a SC of $520 \mathrm{~F} \mathrm{~g}^{-1}$ at $1 \mathrm{~A}$ $\mathrm{g}^{-1}$ and a high rate capacitance of $405 \mathrm{~F} \mathrm{~g}^{-1}$ at $60 \mathrm{~A} \mathrm{~g}^{-1}$ with more than $95 \%$ coulombic efficiency retention after 3500 cycles. ${ }^{21)}$ Leaf-like $\mathrm{CuO}-\mathrm{Cu}_{2} \mathrm{O}$ nanosheets were obtained on $\mathrm{CuF}$ by a one-step simple anodization method. ${ }^{22)}$ The as-prepared electrode exhibited a SC of $1.954 \mathrm{~F} \mathrm{~cm}^{-2}$ at a scan rate of $2 \mathrm{mV} \mathrm{s}^{-1}$, excellent $120 \%$ retention after 5000 cycles, and good coulombic efficiency of $78.2 \%$ at a current density of 2 $\mathrm{mA} \mathrm{cm}{ }^{-2}$. A nickel-cobalt LDH nanosheet film on anodized 3-D CuF was developed using three sequential anodization electrochemical steps. ${ }^{23)}$ The as-prepared Ni-Co LDH hybrid electrode demonstrated an enhanced SC of $2170 \mathrm{~F} \mathrm{~g}^{-1}$ and areal SC of $9.98 \mathrm{~F} \mathrm{~cm}^{-2}$ at $1 \mathrm{~A} \mathrm{~g}^{-1}$, retained the SC of $1875 \mathrm{~F}$ $\mathrm{g}^{-1}$ even at a very high current density of $10 \mathrm{~A} \mathrm{~g}^{-1}$, and showed $80.46 \%$ stability after 2000 cycles at a current density of $6 \mathrm{~A} \mathrm{~g}^{-1}$.23) Kim et al. obtained $\mathrm{CuSe}_{2}$ nanoneedles on $\mathrm{CuF}$ as binder-free electrode materials for ESs where the $\mathrm{CuSe}_{2} / \mathrm{Cu}$ electrode delivered a high SC of $1037.5 \mathrm{~F} \mathrm{~g}^{-1}$ at a constant current density of $0.25 \mathrm{~mA} \mathrm{~cm}^{-2} \cdot{ }^{24}$ ) 


\subsection{Nickel-based self-grown electrode materials}

Currently, nickel-based hydroxide, oxide, and chalcogenide electrode materials are considered favorable for ESs applications because of their environmental friendliness, cost-effectiveness, abundancy, and potentiality of scale-up fabrication. ${ }^{25)}$ Also, these electrode materials have a variety of redox states and good electrical conductivity for charge production and transformation. ${ }^{26,27)} \mathrm{NiF}$ itself contributes some SC performance to self-grown electrode materials, thus improving the overall electrochemical performance. Sun et al. synthesized $\mathrm{Ni}(\mathrm{OH})_{2}$ using a hydrothermal method on $\mathrm{NiF}$ and applied it to ESs. The maximum $\mathrm{SC}$ of $1228 \mathrm{~F}$ $\mathrm{g}^{-1} \mathrm{SC}$ at $5 \mathrm{~A} \mathrm{~g}^{-1}$ and excellent cycling stability with $100 \%$ performance retention were confirmed. ${ }^{28)}$ The $\mathrm{Ni}(\mathrm{OH})_{2}$ nanosheet-films were prepared via a hydrothermal treatment of $\mathrm{NiF}$ at a low temperature using $\mathrm{Fe}\left(\mathrm{NO}_{3}\right)_{3}$ as an oxidant without adding any nickel salts; ${ }^{29)}$ they displayed the $\mathrm{SC}$ of $1100 \mathrm{~F} \mathrm{~g}^{-1}$ at $0.5 \mathrm{~A} \mathrm{~g}^{-1}$ and $35 \%$ loss after 5000 cycles. ${ }^{29)}$ Pan et al. fabricated $\mathrm{Ni}(\mathrm{OH})_{2}$ hexagonal platelets using a self-growth process onto 3-D NiF using a one-step hydrothermal method in the presence of $15 \mathrm{wt} . \% \mathrm{H}_{2} \mathrm{O}_{2}$ aqueous solution without nickel salt, acid, base, or even posttreatment; ${ }^{30)}$ the platelets demonstrated the SC of $2534 \mathrm{~F}$ $\mathrm{g}^{-1}$ at a scan rate of $1 \mathrm{mV} \mathrm{s}^{-1}$ and excellent cycling stability with $97 \%$ capacitance retention after 2000 cycles at a very high scan rate of $50 \mathrm{mV} \mathrm{s}^{-1}$. ${ }^{30)}$ Liu et al. successfully synthesized nickel sulfide (NiS) electrode materials with an amorphous-edge nanobrush morphology on self-sacrificial NiF as the Ni resource, using a facile sulfurization process where an improved electrochemical performance with the SC of $5.59 \mathrm{~F} \mathrm{~cm}^{-2}$ at $10 \mathrm{~mA} \mathrm{~cm}{ }^{-2}$ was obtained. The long-term cycling stability with $94.9 \%$ capacitance retention after 10000 cycles was a very appealing result. ${ }^{31)}$ A facile one-pot hydrothermal route was presented for the synthesis of $\mathrm{Ni}_{3} \mathrm{~S}_{2}$ hierarchical dendrites on $3-\mathrm{D} \mathrm{NiF}$; the dendrites delivered the SCs of $710 \mathrm{~F} \mathrm{~g}^{-1}$ and $470 \mathrm{~F} \mathrm{~g}^{-1}$ at current rates of $2 \mathrm{~A} \mathrm{~g}^{-1}$ and $14 \mathrm{~A} \mathrm{~g}^{-1}$, respectively. ${ }^{32)} \mathrm{Kim}$ et al. obtained nest-like $\mathrm{Ni}_{3} \mathrm{~S}_{2}$ electrode materials over the $\mathrm{NiF}$ substrate surface using a one-pot hydrothermal method with the SC of $1293 \mathrm{~F}$ $\mathrm{g}^{-1}$ at the current density of $5 \mathrm{~mA} \mathrm{~cm}^{-2}{ }^{33)}$ Tong et al. reported the $\mathrm{Ni} @ \mathrm{NiO}$ core-shell electrode synthesis using an activated commercial $\mathrm{NiF}$ in a $3-\mathrm{M} \mathrm{HCl}$ solution; the electrode materials demonstrated an ultrahigh areal capacitance of $2.0 \mathrm{~F} \mathrm{~cm}^{-2}$ at a high current density of $8 \mathrm{~mA} \mathrm{~cm}^{-2}{ }^{34)}$ Lou et al. produced an $\mathrm{Ni}_{3} \mathrm{~S}_{2} @ \beta$-NiS electrode with a pine twig-like structure for high-performance ESs by a facile one-step solvothermal approach..$^{35}$ The electrochemical tests corroborated a SC of $1158 \mathrm{~F} \mathrm{~g}^{-1}$ at a current density of $2 \mathrm{~A} \mathrm{~g}^{-1}$ in a three-electrode cell, where the capacitance remained at $57.8 \%$ at the current density of $50 \mathrm{~A} \mathrm{~g}^{-1}$, signifying the high rate capability of the in-situ grown electrode materials. The obtained $97.4 \%$ retention after 2000 cycles demonstrated excellent electrochemical cycling stability. Huang et al. reported the synthesis of nickel selenide $\left(\mathrm{Ni}_{3} \mathrm{Se}_{2}\right)$ nanosheets on $\mathrm{NiF}$ as $\mathrm{Ni}_{3} \mathrm{Se}_{2} / \mathrm{Ni}$ in the presence of $\mathrm{NaBH}_{4}$ as a reducing agent using a one-step hydrothermal method from $\mathrm{SeO}_{2}$ as a selenide source and $\mathrm{NiF}$ as nickel source. ${ }^{36)} \mathrm{A} \mathrm{SC}$ of $854 \mathrm{~F} \mathrm{~g}^{-1}$ at $1 \mathrm{~A} \mathrm{~g}^{-1}$ was recorded. Mi et al. fabricated hierarchical NiSe microspheres successfully using a solvothermal method where ethylenediamine and $\mathrm{N}, \mathrm{N}$-dimethylformamide were used as mixed solvents. ${ }^{37)}$ An ideal electrochemical performance with the SC of $492 \mathrm{~F} \mathrm{~g}^{-1}$ at a current density of $0.5 \mathrm{~A} \mathrm{~g}^{-1}$ and $100 \%$ retention stability was noted. An in-situ grown NiTe/NiSe composite electrode obtained on $\mathrm{NiF}$ revealed excellent electrochemical properties with the $\mathrm{SC}$ of $1868 \mathrm{~F} \mathrm{~g}^{-1}\left(5.60 \mathrm{~F} \mathrm{~cm}^{-2}\right)$ at $1 \mathrm{~A} \mathrm{~g}^{-1}$ current density. In addition, an asymmetric supercapacitor (ASC) assembled with $\mathrm{NiTe} / \mathrm{NiSe}$ as the positive electrode material and active carbon (AC) as the negative electrode material demonstrated a high energy density of $33.7 \mathrm{~W} \cdot \mathrm{h} \mathrm{kg}^{-1}$ at a the power density of $800 \mathrm{~W} \mathrm{~kg}^{-1}$, suggesting good cycling performance with $86 \%$ retention of the initial capacitance at $2 \mathrm{~A} \mathrm{~g}^{-1}$ even after 5000 cycles. $^{38)}$ The selenium-doped NiTe electrode materials synthesized through a hydrothermal method on $\mathrm{NiF}$ showed the $\mathrm{SC}$ of $998.2 \mathrm{~F} \mathrm{~g}^{-1}$ at the current density of $1 \mathrm{~A} \mathrm{~g}^{-1}$. Furthermore, the selenium-doped NiTe/ AC ASC possessed a superior energy density and power density of $42.7 \mathrm{~W} \cdot \mathrm{h} \mathrm{kg}^{-1}$ and $800.6 \mathrm{~W} \mathrm{~kg}-1$ at the current density of $1 \mathrm{~A} \mathrm{~g}^{-1}$ with $76.4 \%$ cycling stability after 10000 cycles. $^{39)}$

\subsection{Titanium-based electrode materials}

Light-induced water splitting over $\mathrm{TiO}_{2}$ surface was first reported by Fujishima and Honda in $1972 .{ }^{40)}$ Recently, $\mathrm{TiO}_{2}$ has extensively been used in several other applications like in dye-sensitized solar cells, biogenic activities, gas sensors, photocatalysts, ESs, and batteries because of its long-term stability, low fabrication cost, and strong photocatalytic ability ${ }^{41-43)}$ From the different available synthesis protocols, the process of anodization, based on a simple electrochemical oxidizing treatment of $\mathrm{Ti}$, is considered to be most elegant and convenient approach for growing highly oriented $\mathrm{TiO}_{2}$ nanotubes with different diameters and heights. Shinde et $a l .{ }^{44)}$ fabricated self-organized nanoporous tin oxide films using tin anodization from an aqueous electrolyte solution containing oxalic or phosphoric acid. The film demonstrated a maximum specific capacitance of $274 \mathrm{~F} \mathrm{~g}^{-1}$ and long cycle life ability. Li et $a l .{ }^{45)}$ synthesized multilayer $\mathrm{TiO}_{2}$ nanotubes successfully using a multi-pulsed waveform anodization process on commercial valuable titanium foil. Basirun et $a l .{ }^{46}$ ) obtained highly oriented $\mathrm{TiO}_{2}$ nanotube arrays by the self-organizing anodization of titanium foil in organic electrolytes in the presence of fluoride ions. The bamboo-type $\mathrm{TiO}_{2}$ nanotube arrays with higher aspect ratio showed the $\mathrm{SC}$ of $52 \mu \mathrm{F} \mathrm{cm}{ }^{-2}$ in $1 \mathrm{M} \mathrm{Na}_{2} \mathrm{SO}_{4}$ and excellent reversibility characteristics. $\mathrm{Li}$ et al. ${ }^{47)}$ prepared hydrogenated $\mathrm{TiO}_{2}$ on calcining anodized $\mathrm{TiO}_{2}$ nanotubes in a hydrogen atmosphere at 300 to $600^{\circ} \mathrm{C}$; the material showed a SC of $3.24 \mathrm{mF} \mathrm{cm}^{-2}$ at a scan rate of $100 \mathrm{mV} \mathrm{s}^{-1}$. Ambade $e t$ $a{ }^{48)}$ synthesized polythiophene-infiltrated $\mathrm{TiO}_{2}$ nanotubes by controlling the electropolymerization parameters; the nanotubes exhibited an exceptional specific capacitance of 
$640 \mathrm{~F} \mathrm{~g}^{-1}{ }^{47)}$ Lee et $a l .{ }^{49)}$ reported the facile growth of polyaniline (PANI) nanotubes on a titanium nanotube template using electrochemical polymerization. The morphology of the PANI grown on the titanium nanotubes was strongly influenced by the scan rate in the electrochemical polymerization. The $\mathrm{SC}$ of $740 \mathrm{~F} \mathrm{~g}^{-1}$ was measured at the charge-discharge rate of $3 \mathrm{~A} \mathrm{~g}^{-1}$. The $\mathrm{TiO}_{2}$ nanotubes of various diameters obtained from ethylene glycol (EG), polyethylene glycol (PEG), and diethylene glycol (DEG) reagents using the anodization process by Ahmed et al. ${ }^{50)}$ confirmed the importance of nanotube diameter in ES applications; the $\mathrm{TiO}_{2}$ nanotubes prepared from the EG showed tube diameters of $100( \pm 20) \mathrm{nm}$; those obtained from the PEG and DEG were $200( \pm 50)$ and $300( \pm 50) \mathrm{nm}$, respectively. Differences in the diameter and circumference induced variable charge transfer resistance; the electrodes showed $\mathrm{SC}$ values of 14.39, 21.81, and $26.12 \mathrm{~F} \mathrm{~g}^{-1}$ for EG-, PEG-, and DEGmediated $\mathrm{TiO}_{2}$ nanotubes, respectively.

\section{Shortcomings and Perspectives}

The ES devices based on liquid electrolytes demonstrate relatively inferior electrochemical performances, as their energy density is directly proportional to the square of the voltage generated. The ESs based on aqueous electrolytes like $\mathrm{KOH}$ and $\mathrm{NaOH}$ demonstrate operating voltages of approximately $1.5 \mathrm{~V}$. On the other hand, electrode materials used in an acidic electrolyte-mediated ES are chemically unstable and mechanically fragile. Thereby, it is necessary to use conducting and expensive polymeric and organic electrolytes for high voltage operation and thus SC performance. An ideal monolithic self-grown produced electrode material demonstrates high surface area and electrical conductivity. ${ }^{51)}$ On using toxic and explosive dangerous gases like hydrogen sulfide in the dry-annealing process for obtaining self-grown nanostructures, much care should be taken to monitor their trace amounts. It is accepted that, in the anodization process, obtaining a large-area self-grown nanostructure is critical. Being a solution process, defects developing in the product structure cannot be avoided completely in the hydrothermal process. In short, self-grown materials exhibit the lower electronic conductivity by forming narrow resistive spaces across the product/substrate interface, which restrict their practical applications. A costeffective method that can scale up the synthesis of selfgrown structures must be developed. On the other hand, self-grown products with many small grains are promising to enhance the charge carrier mobility in electrochemical energy storage devices. Since the developed electrodes are soft, their conversion into other products through either physical or chemical transformation process can lead different electrochemical properties. Obtained self-grown electrode materials can show the changes in their structure on either the cation or anion exchange process. For example, in the anion exchange process, the conversion of $\mathrm{Ni}(\mathrm{OH})_{2}$ to $\mathrm{NiO} / \mathrm{NiS}$ by oxidation/sulfurization is relatively easy and

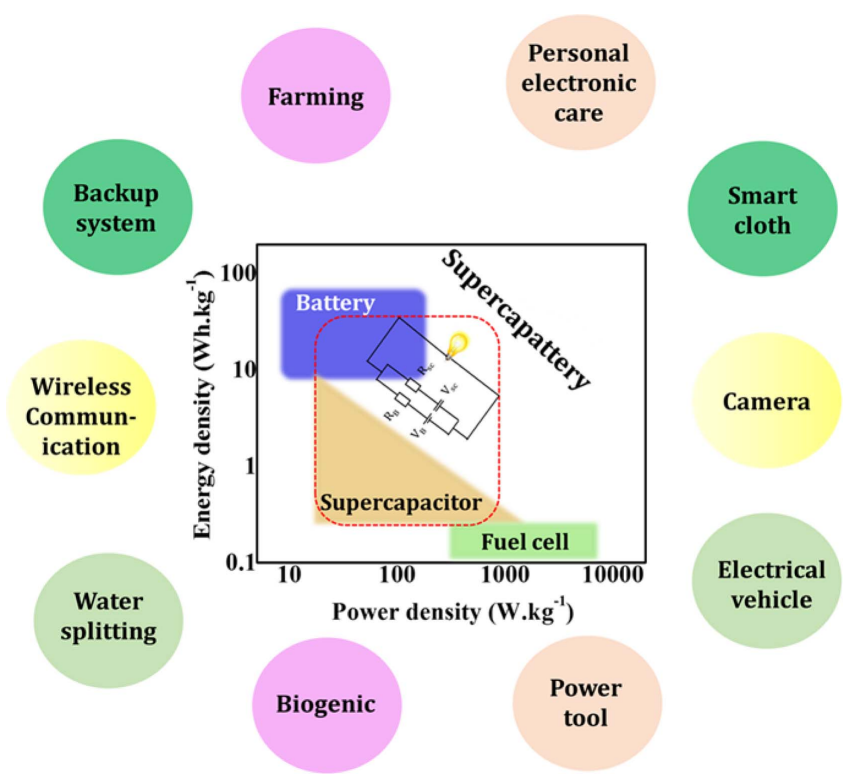

Fig. 7. Energy and power density region, with plausible applications, of supercapattery.

fast. So many new products in the cation exchange process may form on self-grown structures without disturbing their surface architecture and base material framework. For example, $\mathrm{ZnO}$ obtained from $\mathrm{NiO}$ may show different chemical, optical, electrical, physical, and electrochemical properties.

The supercapattery, a combination of battery and supercapacitor technologies, is an upcoming device that may attain both high specific energy and high specific power. It is believed that the specific energy of a supercapattery could exceed to those of batteries and supercapacitors. There are two ways to obtain a supercapattery, i.e., either hybrid form or separately. In the former case, two electrodes, i.e., negative and positive of opposite categories, can be assembled. For example, lithium metal can be used as the negative electrode and $\mathrm{AC} / \mathrm{MnO}_{2}$ as the positive electrode to form, in general, an asymmetric ESs. On coupling a symmetric structure of each, i.e., a battery and supercapacitor in parallel form, as shown in the Fig. 7, a supercapattery can be obtained. The plausible applications of the supercapattery shown in Fig. 7 suggest the future social, industrial and academic stand of this technology. It is worthwhile to mention that, with suitable electrode material and cell design, the performance of the supercapattery depends upon the nature of GCD obtained, i.e., battery or supercapacitor type. For example, if the obtained GCD curve shows battery features, then data presentation and analysis should be in consistent with those used for batteries rather than supercapacitors and vice-versa.

\section{Conclusions}

The overview provided here highlighted the importance of various nanostructures in electrochemical energy storage 
devices, particularly electrochemical supercapacitors. The advantages and disadvantages of the available chemical and physical methods for fabricating these nanostructures have been briefly emphasized. The assets and the available synthesis methods of self-grown nanostructures before their use in electrochemical energy storage devices are described in detail. The operation mechanisms and applicable electrode materials with their affiliated properties are also briefly addressed. Electrochemical supercapacitors assembled on self-grown nanostructures have demonstrated structural robustness and chemical inertness for long-term and high cyclability rate features. High surface area, smaller series resistance, and the possibility of superstructure formation can make self-grown nanostructures more versatile for their potential use in portable, stretchable, and miniaturized energy storage devices. ${ }^{51-54)}$ Forming novel self-grown materials with various morphologies and electrochemical energy storage properties remains technically and scientifically challenging and interesting. Finally, the portable energy storage device called the supercapattery, having high specific energy and power, will be highly beneficial from electronic industrial perspectives.

\section{Acknowledgments}

This study was supported by: (a) The Global Frontier Program through the Global Frontier Hybrid Interface Materials (GFHIM) of the National Research Foundation of Korea (NRF) funded by the Ministry of Science, ICT \& Future Planning (2013 M3A6B1078874), and (b) National Core Research Centre (NCRC) grant 2015M3A6B1065262.

\section{REFERENCES}

1. L. Dong, C. Xu, Y. Li, Z. Huang, F. Kang, Q. Yang, and X. Zha, "Flexible Electrode and Supercapacitors for Wearable Energy Storage a Review by Category," J. Mater. Chem. A, 4 [13] 4659-85 (2016).

2. M. Huang, F. Li, F. Dong, Y. Zhang, and L. Zhang, " $\mathrm{MnO}_{2}$ based Nanostructures for High-Performance Supercapacitors," J. Mater. Chem. A, 3 [43] 21380-423 (2015).

3. P. Kulkarni, S. Nataraj, R. Balakrishna, D. Nagaraju, and M. Reddy, "Nanostructured Binary and Ternary Metal Sulfides: Synthesis Methods and Their Application in Energy Conversion and Storage Devices," J. Mater. Chem. A, 5 [42] 22040-94 (2017).

4. Q. Xia, N. Shinde, T. Zhang, J. Yun, A. Zhou, R. Mane, S. Mathur, and K. Kim, "Seawater Electrolyte-Mediated High Volumetric MXene-based Electrochemical Symmetric Supercapacitors," Dalton Trans., 47 [26] 8676-82 (2018).

5. U. Gulzar, S. Goriparti, E. Miele, T. Li, G. Maidecchi, A. Toma, F. Angelis, C. Capiglia, and R. Proietti Zaccaria, "Next-generation Textiles: from Embedded Supercapacitors to Lithium Ion Batteries," J. Mater. Chem. A, 4 [43] 16771-800 (2016)

6. B. Li, M. Zheng, H. Xue, and H. Pang, "High Performance Electrochemical Capacitor Materials Focusing on Nickel
Based Materials," Inorg. Chem. Front., 3 [2] 175-202 (2016).

7. X. Yu and X. Lou, "Mixed Metal Sulfides for Electrochemical Energy Storage and Conversion," Adv. Energy Mater., 8 [3] 1701592 (2018).

8. G. Chen, "Understanding Supercapacitors Based on Nanohybrid Materials with Interfacial Conjugation," Prog. Nat. Sci.: Mater. Int., 23 [3] 245-55 (2013).

9. T. Broussea, D. Bélangerc, and J. Long, "To Be or Not To Be Pseudocapacitive," J. Electrochem. Soc., 162 [5] A518589 (2015).

10. D. Dubal, J. Kim, Y. Kim, R. Holze, C. Lokhande, and W. Kim, "Supercapacitors Based on Flexible Substrates: An Overview," Energy Technol., 2 [4] 325-41 (2014).

11. X. Xia, Y. Zhang, D. Chao, C. Guan, Y. Zhang, L. Li, X. Ge, I. Bacho, J. Tu, and H. J. Fan, "Solution Synthesis of Metal Oxides for Electrochemical Energy Storage Applications," Nanoscale, 6 [10] 5008-48 (2014).

12. X. Zhao, B. Anchez, P. Dobson, and P. Grant, "The Role of Nanomaterials in Redox-based Supercapacitors for Next Generation Energy Storage Devices," Nanoscale, 3 [3] 839-55 (2011).

13. K. Shehzad, Y. Xu, C. Gaoc, and X. Duan, "Three-Dimensional Macro-Structures of Two-Dimensional Nanomaterials," Chem. Soc. Rev., 45 [20] 5541-88 (2016).

14. W. Yang, G. Cheng, C. Dong, Q. Bai, X. Chen, Z. Peng, and Z. Zhang, "NiO Nanorod Array Anchored Ni Foam as a Binderfree Anode for High-Rate Lithium Ion Batteries," J. Mater. Chem. A, 2 [47] 20022-29 (2014).

15. A. Dominguez, O. Quispe, and J. Gonzalez, "Characterization of Ni Thin Films Following Thermal Oxidation in Air,” J. Vac. Sci. Technol. B, 32 [5] 051808 (2014).

16. J. Sagu, K. Wijayantha, M. Bohm, S. Bohm, and T. Rout, "Anodized Steel Electrodes for Supercapacitors," ACS Appl. Mater. Interfaces, 8 [9] 6277-85 (2016).

17. T. Burleigh, T. D. Dotson, K. Dotson, S. Gabay, T. Sloan, and S. Ferrell, "Anodizing Steel in $\mathrm{KOH}$ and $\mathrm{NaOH}$ Solutions," J. Electrochem. Soc., 154 [10] C579-86 (2007).

18. Y. Konno, E. Tsuji, P. Skeldon, G. Thompson, and H. Habazaki, "Factors Influencing the Growth Behaviour of Nanoporous Anodic Films on Iron Under Galvanostatic Anodizing," J. Solid State Electrochem., 16 [12] 3887-96 (2012).

19. W. Lu, Y. Sun, H. Dai, P. Ni, S. Jiang, Y. Wang, Z. Li, and Z. Li, "CuO Nanothorn Arrays on Three-dimensional Copper Foam as an Ultra-highly Sensitive and Efficient Nonenzymatic Glucose Sensor," RSC Adv., 6 [20] 16474-80 (2016).

20. J. Wan, A. Pang, D. He, J. Liu, H. Suo, and C. Zhao, "A High-Performance Supercapacitor Electrode Based on Three-Dimensional Poly-Rowed Copper Hydroxide Nanorods on Copper Foam,” J. Mater. Sci.: Mater. Electron., 29 [4] 2660-67 (2018).

21. Y. Lu, H. Yan, K. Qiu, J. Cheng, W. Wang, X. Liu, C. Tang, J. Kim, and Y. Luo, "Hierarchical Porous CuO Nanostructures with Tunable Properties for High Performance Supercapacitors," RSC Adv., 5 [14] 10773-81 (2015).

22. D. He, G. Wang, G. Liu, H. Suoa, and C. Zhao, "Construction of Leaf-like $\mathrm{CuO}-\mathrm{Cu}_{2} \mathrm{O}$ Nanocomposites on Copper Foam for High-Performance Supercapacitors," Dalton 
Trans., 46 [10] 3318-24 (2017).

23. Y. Liu, X. Teng, Y. Mia, and Z. Chen, "A New Architecture Design of Ni-Co LDH-Based Pseudocapacitors," J. Mater. Chem. A, 5 [46] 24407-15 (2017).

24. P. Pazhamalai, K. Krishnamoorthy, and S. Kim, "Hierarchical Copper Selenide Nanoneedles Grown on Copper Foil as a Binder Free Electrode for Supercapacitors," Int. J. Hydrogen Energy, 41 [33] 14830-35 (2016).

25. S. Ni, X. Lv, J. Ma, X. Yang, and L. Zhang, "A Novel Electrochemical Reconstruction in Nickel Oxide Nanowalls on $\mathrm{Ni}$ Foam and the Fine Electrochemical Performance as Anode for Lithium Ion Batteries," J. Power Sources, 270 564-68 (2014).

26. W. Yang, G. Cheng, C. Dong, Q. Bai, X. Chen, Z. Peng, and Z. Zhang, "NiO Nanorod Array Anchored Ni Foam as a Binder-free Anode for High-Rate Lithium Ion Batteries," J. Mater. Chem. A, 2 [47] 20022-29 (2014).

27. Li Yang, L. Qian, X. Tian, J. Li, J. Dai, Y. Guo, and D. Xiao, "Hierarchically Porous Nickel Oxide Nanosheets Grown on Nickel Foam Prepared by One-Step in situ Anodization for High-Performance Supercapacitors," Chem. Asian J., 9 [6] 1579-85 (2014).

28. B. Hu, X. Qin, A. Asiri, K. Alamry, A. Youbi, and X. Sun, "Fabrication of $\mathrm{Ni}(\mathrm{OH})_{2}$ Nanoflakes Array on Ni Foam as a Binder-free Electrode Material for High Performance Supercapacitors," Electrochim. Acta, 107 339-42 (2013).

29. J. M. Xu, K. Ma, and J. Cheng, "Controllable in situ Synthesis of $\mathrm{Ni}(\mathrm{OH})_{2}$ and $\mathrm{NiO}$ Films on Nickel Foam as Additive-free Electrodes for Electrochemical Capacitors," $J$. Alloys Compd., 653 88-94 (2015).

30. L. Li, J. Xu, J. Lei, J. Zhang, F. McLarnon, Z. Wei, N. Li, and F. Pan, "A One-Step, Cost-Effective Green Method to in Situ Fabricate $\mathrm{Ni}(\mathrm{OH})_{2}$ Hexagonal Platelets on $\mathrm{Ni}$ foam as Binder-Free Supercapacitor Electrode Materials," $J$. Mater. Chem. A, 3 [5] 1953-60 (2015).

31. X. Lia, G. Chen, K. Xiao, N. Li, T. Ma, and Z. Liu, "SelfSupported Amorphous-Edge Nickel Sulfide Nanobrush for Excellent Energy Storage," Electrochim. Acta, 255 153-59 (2017).

32. Z. Zhang, Z. Huang, L. Ren, Y. Shen, X. Qi, and J. Zhong, "One-Pot Synthesis of Hierarchically Nanostructured $\mathrm{Ni}_{3} \mathrm{~S}_{2}$ Dendrites as Active Materials for Super Capacitors," Electrochim. Acta, 149 316-23 (2014).

33. K. Krishnamoorthy, G. Veerasubramani, S. Radhakrishnan, and S. J. Kim, "One Pot Hydrothermal Growth of Hierarchical Nanostructured $\mathrm{Ni}_{3} \mathrm{~S}_{2}$ on Ni Foam for Supercapacitor Application," Chem. Eng. J. Chem., 251 116-22 (2014).

34. M. Yu, W. Wang, C. Li, T. Zhai, X. Lu, and Y. Tong, "Scalable Self-Growth of Ni@NiO Core-Shell Electrode with Ultrahigh Capacitance and Super-Long Cyclic Stability for Supercapacitors," NPG Asia Mater., 6 e129 (2014).

35. W. Li, S. Wang, L. Xin, M. Wu, and X. Lou, "Single-Crystal B-NiS Nanorod Arrays with a Hollow Structured $\mathrm{Ni}_{3} \mathrm{~S}_{2}$ Framework for Supercapacitor Applications," J. Mater. Chem. A, 4 [20] 7700-9 (2016).

36. S. Jiang, J. Wu, B. Ye, Y. Fan, J. Ge, Q. Guo, and M. Huang, "Growth of $\mathrm{Ni}_{3} \mathrm{Se}_{2}$ Nanosheets on Ni Foam for Asymmetric Supercapacitors," J. Mater. Sci.: Mater. Elec- tron., 29 [6] 4649-57 (2018).

37. K. Guo, F. Yang, S. Cui, W. Chen, and L. Mi, "Controlled Synthesis of 3D Hierarchical NiSe Microspheres for HighPerformance Supercapacitor Design,” RSC Adv., 6 [52] 46523-30 (2016).

38. B. Ye, M. Huang, Q. Bao, S. Jiang, J. Ge, H. Zhao, L. Fan, J. Lin, and J. Wu, "Construction of NiTe/NiSe Composites on Ni Foam for High-Performance Asymmetric Supercapacitor," ChemElectroChem, 5 [3] 507-14 (2018).

39. B. Ye, M. Huang, S. Jiang, L. Fan, J. Lin, and J. Wu, "Insitu Growth of Se-Doped NiTe on Nickel Foam as Positive Electrode Material for High-Performance Asymmetric Supercapacitor," Mater. Chem. Phys., 211 389-98 (2018).

40. A. Fujishima and K. Honda, "Electrochemical Photolysis of Water at a Semiconductor Electrode," Nature, 238 37-8 (1972).

41. P. Yang, D. Chao, C. Zhu, X. Xia, Y. Zhang, X. Wang, P. Sun, B. Tay, Z. Shen, W. Mai, and H. Jin Fan, "UltrafastCharging Supercapacitors Based on Corn-Like Titanium Nitride Nanostructures," Adv. Sci., 3 [6] 1500299 (2016).

42. M. Salari, S. Aboutalebi, K. Konstantinov, and H. Liu, "A Highly Ordered Titania Nanotube Array as a Supercapacitor Electrode," Phys. Chem. Chem. Phys., 13 [11] 5038-41 (2011).

43. M. Zhou, A. M. Glushenkov, O. Kartachova, Y. Li, and Y. Chena, "Titanium Dioxide Nanotube Films for Electrochemical Supercapacitors: Biocompatibility and Operation in an Electrolyte Based on a Physiological Fluid," $J$. Electrochem. Soc., 162 [5] A5065-69 (2015).

44. D. Shinde, D. Lee, S. Patil, I. Lim, S. Bhande, W. Lee, M. Sung, R. Mane, N. Shrestha, and S. Han, "Anodically Fabricated Self-organized Nanoporous Tin Oxide Film as a Supercapacitor Electrode Material," RSC Adv., 3 [24] 9431-35 (2013).

45. L. Zheng, Y. Dong, H. Bian, C. Lee, J. Lu, and Y. Li, "SelfOrdered Nanotubular $\mathrm{TiO}_{2}$ Multilayers for High-Performance Photocatalysts and Supercapacitors," Electrochim. Acta, 203 257-64 (2014).

46. Z. Endut, M. Hamdi, and W. Basirun, "Supercapacitance of Bamboo-type Anodic Titania Nanotube Arrays," Surf. Coat. Technol., 215 75-8 (2013).

47. X. Lu, G. Wang, T. Zhai, M. Yu, J. Gan, Y. Tong, and Y. $\mathrm{Li}$, "Hydrogenated $\mathrm{TiO}_{2}$ Nanotube Arrays for Supercapacitors," Nano Lett., 12 [3] 1690-96 (2012).

48. R. Ambade, S. Ambade, N. Shrestha, Y.-C. Nah, S.-H. Han, W. Lee, and S.-H. Lee, "Polythiophene Infiltrated $\mathrm{TiO}_{2}$ Nanotubes as High-Performance Supercapacitor Electrodes," Chem. Commun., 49 [23] 2308-10 (2013).

49. S. Mujawar, S. Ambade, T. Battumur, R. Ambade, and S.H. Lee, "Electropolymerization of Polyaniline on Titanium Oxide Nanotubes for Supercapacitor Application," Electrochim. Acta, 56 [12] 4462-66 (2011).

50. A. Al-Osta, V. V. Jadhav, M. K. Zate, R. S. Mane, K. N. Hui, and S.-H. Han, "Electrochemical Supercapacitors of Anodized Brass Templated NiO Nanostrutured Electrodes," Scr. Mater., 99 29-32 (2015).

51. E. S. Jang, "Precent Progress in Synthesis of Plate-like $\mathrm{ZnO}$ and its Applications: A Review," J. Korean Ceram. Soc., 54 [3] 167-83 (2017). 
52. J. Kim and J. H. Lim, "Organic-Inorganic Hybrid Thermoelectric Materials Synthesis and Properties," J. Korean Ceram. Soc., 54 [4] 272-77 (2017).

53. S. Kang, R. C. Pawar, T. J. Park, J. G. Kim, S. H. Ahn, and C. S. Lee, "Minimization of Recombination Losses in 3D Nanostructured $\mathrm{TiO}_{2}$ Coated with Few Layered g- $\mathrm{C}_{3} \mathrm{~N}_{4}$ for Extended Photo-Response," J. Korean Ceram. Soc., 53 [4] 393-99 (2016).

54. N. Shinde, A. Jagadale, V. Kumbhar, T. Rana, J. Kim, and C. Lokhande, "Wet Chemical Synthesis of $\mathrm{WO}_{3}$ Thin Films for Supercapacitor Application," Korean J. Chem. Eng., 32 [5] 974-79 (2015). 